\title{
A Brief Study of Sectarian Conflicts in India
}

\author{
Rui Hu ${ }^{1, a}$, Keping Tian 2,b \\ ${ }^{1}$ Department of South Asian Languages and Literature, Guangdong University of Foreign Studies, \\ No.2 North Baiyun Avenue, Baiyun District, Guangzhou, China. \\ ${ }^{2}$ Department of South Asian Languages and Literature, Guangdong University of Foreign Studies, \\ No.2 North Baiyun Avenue, Baiyun District, Guangzhou, China. \\ aEmail:hr20062008@sina.com, ${ }^{\mathrm{b}}$ Email:Tiankeping1@gmail.com
}

Keywords: India; Sectarian; Conflict; Religions

\begin{abstract}
In recent decades, India has made great progress in Comprehensive National Power, which has attracted widespread attention from the whole world. However, in this process, India has to face many obstacles, of which the most prominent is Sectarian conflicts. Since independence India has set secularism as the basis of the state, but sectarian contradictions and conflicts have never ceased to affect the development of India. Making study about sectarian conflicts of India is very beneficial for the deeper understanding of India.
\end{abstract}

\section{Introduction}

India was one of the countries which have the most complex religion condition. Hinduism, Islam, Sikhism, Buddhism and Christianity- almost all major religions of the world can be found here. All these religion sects have many believers here, and they cannot but live together to share the same developing process, and go ahead together with their country, experiencing both prosperity and turbulence. In India, there are not only a wide range of religions; the differences between these sects are also enormous. After the founding of the Congress government, India established the principle of secularism, but in the actual implementation of the principle there is a big lack from the theoretical principle, and the government performs the secularism far from adequately. Sectarian forces have gradually extend to economic and political field, sectarian doctrine get more and more close to politics, and began to intervene political development. To make study about the issue and religious conflicts in India is beneficial for understanding all aspects of Indian: society, politics, economy, culture, religion, etc. and, also would help keep South Asia's peace and stability in the Asia-Pacific region.

\section{Sectarian Conflicts in India}

There are many sectarian conflicts in India, but generally speaking all the major conflicts will involve Hinduism. The main conflicts include: Hindu-Muslim conflict, Hindu-Sikh conflict, Hindu-Christian conflict, and so on.

\section{Hindu-Muslim Conflict}

The contradiction between Hindu and Muslim began to intensify from British colonial rule. British government employed the policy of dividing, which aimed at undermining the solidarities and relations between Hindus and Muslim and, splitting the two sects into two separated groups which would be hostile with each other. At last, British government achieved its goals: the two sects gradually went from unity to separation and contradictions, and eventually split India into two counties: India and Pakistan. During the partition of India and Pakistan, sectarian violence between Hindus and Muslims also reached the peak. Hindus Mahasabha, Rashtriya Swayamasevak Sangh and other organizations tried their best to spread religious fanaticism and hostility, inciting Hindus to emigrate from Pakistan; similarly, the Muslim League also took tit for tat measures, desperately exhorting Muslims to move out of India. Due to the moves of both sides, unprecedented large-scale brutal bloodshed and vendetta occurred in the migration process, which was very rare in Indian 
history. Within less than a few months, many towns and villages suddenly were ruined, full of refugees and homeless people, lying dead everywhere. The sight were so horrible that anyone could hardly bear to see. According to statistics, at least 50 people were killed and 12 million people homeless. The number of refugees fleeing from both sides was up to 14 million, and 25 million more suffered huge economic losses.

Since India's independence, the contradictions and conflicts between Hindus and Indian Muslims did not ease, but continue, or even become more intensified day by day. Since the 1970s, the general trend of conflict between Hindus and Muslim are getting more frequent, the region and scale involved being wider. In Earlier times, sectarian conflicts between Hindu and Muslim occurred mostly in northern India, but have now been extended to the south of India, and the trend continues to spread wider. In the past, sectarian violence is generally limited to the city, but has now been extended to the vast rural areas. According to Indian government statistics, in 1988, in more than 88 counties those conflicts occurred, whereas the No. of such counties in 1989 was 110, compared with the total counties No. of India: 452. The occurrences of sectarian conflict are on the steady increase. At the same time, the violence are also being intensified constantly, which have caused more and more serious result. For example, the outbreak of the destruction of the temple in Ayodhya resulted in national sectarian conflict in 1992, which cause 2,000 people dead, and about 5,500 injured, of which two thirds are Muslim.

\section{Hindu-Sikh Conflict}

After the India-Pakistan war, Punjab province was established under the requirements of Sikhs. From then on Sikhs have transferred Punjab into a prosperous and flourishing province. Sikhs were good at farming, and they also excelled in the Indian business community and the military, all these bring them prosperity and, a kind of feeling superior to others. In the early 1970s, on behalf of the interests of Sikh, Akali party stated that the Sikhs should be treated as an independent autonomous region, should enjoy all the powers except defense, foreign affairs, transport and currency rights. The statement was rejected by India's central government. In 1980s, in order to oppose the Hindus and to fight against exclusion, Sikhs set off a national autonomous movement; some even proposed the establishment of "Khalistan country", which goal is to establish a Sikh nation. Before this, for a long time, Punjab state was leaded by the Congress and Akali party in turn, but at that time the political situation began to be in turmoil. After 1983, the situation deteriorated sharply in the state, because the central government did not meet the requirements. Sikhs clashed with police, more than 10 people dead. In 1984 the Indian government decided to take repression steps, declared the whole territory of the Punjab region being in "serious disturbances", and took the "Operation Blue Star" military action in June, sent military and police to this region and attacked Sikh's holy temple- Amritsar Golden Temple. After this incident, more than 5,000 Sikh soldiers took part in the mutiny in Bihar, Rajasthan and some other areas. In October 31 that year, Sikh extremists took revenge against Prime Minister Indira Gandhi and killed her, which further caused more brutal action by Hindus. Throughout the country mutual killings happened between Hindus and Sikhs. The situation didn't ease until the central government made certain concessions, after the new state government was established in 1992.

\section{Conflicts between Hinduism and Other Religions}

In addition to above contradictions, in India there are various other sectarian conflicts, for example, conflict between Hindu and Christian, conflict between Hindu and Buddhist, and so on.

Different from Muslims, Christians and Buddhists in India are only a small population. For example, Christians accounted for only $2.3 \%$ of the total population in India. They live in the rural area in south India and other economically backward regions. In the eyes of ordinary Indians, Christianity and Buddhism in India have not caused serious consequences like Islam did. But some Hindus nationalists still take Christians and Buddhists as their enemy. Hinduism organizations are hostile with the action of converting into Christianity from Hindus. For Hindus, the converting means betraying their religion and their nation. So they are dedicated to making these converted people come back to Hinduism, and fighting against Christian missionary activities. In India, most Christians and Buddhists are formerly low-caste Hindus or "untouchables", before conversion most of them 
being in the politically and economically underprivileged ranks. But after the conversion these former low-caste Hindus or even untouchables get equal position with upper-caste Hindus, thanks to the government's policy, and some Christians, Buddhists even become social elites. This phenomenon is hard to accept for higher Hindus, who is unwilling to put up with their rising in social and economic position.

High caste Hindus believe that these infidels snatched opportunities in economic, political and other fields, so they are more hostile with these sects. Therefore, some of sectarian conflict often happened across the whole country. Take a brutal collision as an example: from August to October, 2008, a large-scale and long-time conflict between Hindus and Christians took place in Orissa, Karnataka and Madhya Pradesh and other places. A number of Christian churches were burned, Christian established schools and orphanages were destroyed, many Christians and missionaries were killed, robbed, attacked. The violence was so horrible which drove about 50,000 people homeless.

\section{The Reasons for These Conflicts}

The reasons why sectarian contradictions keep haunting India for so long time and so large scale can be explained from the following aspects:.

\section{Historical Factors}

After 19th century the Indian nationalist movement increasingly awakened, so British colonialists were deeply disturbed. Especially in 1857 Indian national uprising, it seemed that Hindus and Muslims began to unite to give heavy blow to the British. They recognized that only the use of sectarian conflicts, instigating Hindus and Muslims in the relationship can help them maintain their own stable ruling. British cannot but to damage the relations between the two sects. British government employed the policy of dividing, instigate the two sects go far away, which aimed at undermining the solidarities and relations between Hindus and Muslim and, splitting the two sects into two separated groups which would be hostile with each other.

British colonialists introduced Government Act of India of 1935 that took two fundamental issues, first about the establishment of India Federation, and second about provincial autonomy for Indian people. This act caused the communal tension in India, because one point of its rule was giving separated electoral votes based on communal award. British authorities openly gave Muslims special privileges, and local governments at all levels increase the quota for Muslims in the selection of government officials. They declared that the Congress only represented and promoted the interests of Hindus, never caring about the interest of Muslims, undermining the relations between Muslim and Congress Party. British authorities gave separated voting rights to Muslim, and give them higher proportion of the population quota seats. As a result, other religion sects also expected to follow Muslim, and, British agreed to their requirement, formally established the sectarian voting system, dividing Indians into Hindus, Muslims, Sikhs, Christians and other units as separate election groups.

At last, British government achieved its goals: the religion sects gradually went from unity to separation and contradictions. Effect of sectarian electoral system is very bad, it makes the sectarian forces as a legitimate political force boarded the stage of history, and further stimulate the various religious groups to struggle for power, exacerbated the contradictions and conflicts between sects, planted seeds for the subsequent prolonged sectarian struggle.

\section{Political Factors}

After independence India government's policy mistakes was also an important factor in the development of sectarianism. Just because those politicians have seen the harmful effect of sectarianism, they set secularism as the basis of the state after independence. Indian constitution clearly stipulates: India should be lead to a secular democratic republic country. The main content of secularism is religious freedom, religious equality and clear division between politics and religion. In the 1950 s to 1970 s, Congress party basically implement this principle, maintain distance and resolutely crack down on sectarian parties and sectarian forces, so the secular system of the country can the effectively function, although some sectarian organizations and political parties were active from time to time, but were always excluded from the mainstream of Indian politics. 
In the late 1970s and early 1980s, the situation began to change. The Congress party lost its dictatorship in central government and lost its overwhelming influence, as a result they began to pay much more attention to the result of election. Rather than cracking down sectarianism, they put up with it or even made use of it. The Congress and other parties gradually violated the original intention of sectarianism and took a pragmatic approach in order to meet the interests and achieve their campaign. the decline of the Congress Party, the ruling party lost in a central position. Under this circumstance, in order to win the election, they began to pay attention to cater to the feelings of Hindus. For example, Indira Gandhi began to attend the rituals of Hinduism; the Congress even take steps on contrary to the principle of secularism, show support for sectarian groups publicly, and even made alliance with Shiv Sena in Maharashtra and supported Sikhs in Punjab. This made the Congress's secularism policy severely damaged. In the 1980s, the BJP began to rise, and the use of Hindus sectarianism continued to grow, causing increasing sectarian sentiments among common people. Whereas the Congress party failed to take effective countermeasures, in the election it did not put forward any attractive slogans. When the temple conflict became fiercer, the Congress government didn't take any effective steps to control the situation. A large number of fanatical Hindus break through the cordon, demolished the Babri mosque, triggering a large-scale sectarian bloodshed. Muslims believe that the government in favor of Hindus. So, to some extent the development of India's sectarian could be attributed to the government and political factors.

\section{Economic Factors}

Since independence India has made great achievements in economic and social development, people's living standards has been improved steadily, and the absolute impoverishment has been eased to great extent. However, the relative poverty is on the rise, which means the gap between rich and poor has become wider these years, which made a large number of people dissatisfied with society. Such discontent and grievance also contributed to the growing social and sectarian contradictions. Indian society is the use of the dominant class to transfer the sectarian conflict, but in reality is its long-term development of a soil. Currently the difference between rich and poor in India is very serious. In the era of economic globalization, Hindus and Muslims have to compete in terms of employment, promotion and education intensely. The competence and contradiction in economic field manifested in the form of religious conflict.

In India, most Christians, Buddhists etc. were formerly low-caste Hindus or "untouchables", and most of them are from the bottom of society. According to some report, although Muslims account for more than $13 \%$ of the Indian population, but in political and economic leading position only account for about $2 \%$, much lower than their proportion of the population. Muslim and other religions are more and more dissatisfied with the government, and cry for equality and justice in economic and political field. This in turn causes a strong reaction among Hindus and further stimulates the rise of Hindu sectarian sentiments. In addition, backward-caste Hindus are in lack of skills and opportunity in learning English and mastering modern knowledge, whereas upper-caste Hindus are unwilling to let the backward castes to enter the industrial, commercial and software industry, making many of them unemployed. These poor young Hindus would become a great destructive power and thugs controlled by high caste Hindus.

\section{Cultural Factors}

Based on the understanding of the bad effect of sectarianism, Nehru chose secularism as the basis of the state after independence, and for the sake of national unity and identity, he has taken a series of measures from legislative, economic and diplomatic aspects. However, in practice, Nehru ignored the psychological and emotional integration among different religions. They incorrectly deemed that the legislative and economic development will naturally lead to spiritual unity.

The difference between different religions is great, especially the difference between Hinduism and Islam. Hindus and Muslims are radically different, or even completely opposite in faith, rituals and lifestyle. Hinduism is a polytheistic religion, ten million gods being worshiped. Islam is monotheistic religion, only worship Allah. Idolatry prevails in Hindus. There are many complicated rites and ceremonies, whereas Islam is against idol worship. Hindus emphasize on individual practice, but Islam claims that saving is from the prophets. In lifestyle, Hindus worship cows, considered 
slaughter and abuse of cattle is a sin, but Muslims have the habit of eating beef, in Eid al-Adha every year they will give beef and mutton as gifts to each other. These cultural differences make religious conflict in India be confrontational, persistent and recurrent, whose influence will by no means be eliminated in short term. Lack of cultural identity can also directly result in the discord between different religions. While tangled with political and economic interests together, the discord and contradiction became more complex and intensive. When various religions want to defend their beliefs and political and economic interests, there will be collisions and conflicts.

In fact, cultural identity dilemma is the basic cause of sectarian contradiction and conflict, other factors, such as politics, economic interests, etc. all being on the basis of cultural factors.

\section{Conclusion}

Just as mentioned before, India possesses the most complex religious situation among the whole world, and almost all major religions of the world can be found in India. Under such conditions, sectarian contradictions and conflicts existed across the whole country. Like the many episodes of sectarian violence that have occurred all around the world, it is reasonable that there are economic and political components to Indian sectarian conflicts. In addition, the British colonial ruler has played a catalytic role in inciting and intensifying these contradictions and conflicts. However, cultural identity problem should be the fundamental factor. The differences and contradictions between Hindu and other sects in beliefs, customs, living style, values etc. are the basic factors for all the conflicts.

\section{Acknowledgements}

This work was financially supported by Innovative School Project in Higher Education of Guangdong, China (Grant No. GWTP-FT-2014-11), and supported by 2014 Young Creative Talents Project of the Education Department of Guangdong Province, China (Humanities and Social Sciences) (Project Name: The impacts of sectarian conflicts of India on its domestic politics ,Grant No. 35)

\section{References}

[1] Raju G.C.Thomas: Democracy, Security and Development in India (St. Martin's Press, New York 1996).

[2] Uma KapilaIndian: Economy Since Independence, 1998-99 (Acadimic Foundation, Delhi 1998).

[3] Youwei Zhong: Journal of Anhui Institute of Education, vol.2 (2005).

[4] Greg: Government and Politics in South Asia (Westview Press 1993).

[5] Ramesh Thakur: India in the World: Neither Rich, powerful, nor Principled, Foreign Affair, July-August(1997).

[6] R. Basant: Education and Employment among Muslims in India: An Analysis of Patterns and Trends, Working Paper, Indian Inst.Management, Ahmedabad( 2012).

[7] S. Wilkinson: Votes and Violence: Electoral Competition and Ethnic Riots in India. (Cambridge Univ. Press, Cambridge 2004). 